\title{
Altered Neurotransmission Prior to Cognitive Decline in A $\beta P P / P S 1$ Mice, a Model of Alzheimer's Disease
}

\author{
Kevin N. Hascup a and Erin R. Hascup ${ }^{\mathrm{a}, \mathrm{b}, *}$ \\ a Department of Neurology, Center for Alzheimer's Disease and Related Disorders, Southern Illinois University \\ School of Medicine, Springfield, IL, USA \\ ${ }^{\mathrm{b}}$ Department of Pharmacology, Southern Illinois University School of Medicine, Springfield, IL, USA
}

Accepted 1 October 2014

\begin{abstract}
Indirect evidence supports altered glutamate signaling with Alzheimer's disease, however, it is not known if glutamate neurotransmission is impacted prior to cognitive decline. We examined cognition and glutamate neurotransmission in 2-4 month AßPP/PS1, an Alzheimer's disease model, and age-matched control mice. There were no differences in learning and memory as assessed by Morris water maze. However, in vivo electrochemical measures of potassium-evoked glutamate release in the $\mathrm{CA} 1$, but not the CA3 or dentate, was significantly elevated in AßPP/PS1 mice. These data support changes in the glutamatergic system that precedes cognitive decline in a mouse model of Alzheimer's disease.
\end{abstract}

Keywords: Alzheimer's disease, biological markers, cognition, glutamic acid

\section{INTRODUCTION}

Alzheimer's disease (AD) is an age-related neurodegenerative disorder resulting in severe impairment in new learning and memory, and eventually progressive dementia. In the United States, AD is the 6th leading cause of death, and over 5.2 million Americans have the disease [1]. There has not been a new FDA approved drug to treat AD since 2003, therefore, it is imperative that we find a novel therapeutic target or opportune treatment window that exists prior to cognitive decline with the potential to slow or stop AD progression. Increasing evidence supports the glutamatergic system as a possible early biomarker that meets these criteria [2-11].

Glutamate (Glu) is the major excitatory neurotransmitter in the mammalian central nervous system

\footnotetext{
*Correspondence to: Erin R. Hascup, Department of Neurology, Center for Alzheimer's Disease and Related Disorders, Southern Illinois University School of Medicine, P.O. Box 19628, Springfield, IL 62794-9628, USA. Tel.: +1 217545 6988; E-mail: ehascup@siumed.edu.
}

(CNS), and several studies have implicated its involvement in AD pathologies including soluble amyloid- $\beta$ $(A \beta)_{42}$, deposition of $A \beta$ in plaques, and hyperphosphorylated tau protein in tangles [6, 12-28]. Recent evidence from A $\beta P P / P S 1$ mice, a model of $\mathrm{AD}$, and postmortem human CNS tissue suggest that altered extracellular Glu levels and function change as AD progresses. For example, vesicular Glu transporter 1 boutons are elevated in pre-clinical AD cases (possibly through interaction with soluble $A \beta$ ) but are significantly reduced and associated with $A \beta$ plaque accumulation in end-stage AD cases and A $\beta P P / P S 1$ mice [12]. Given these findings, we believe that altered Glu neurotransmission may be instrumental not only in presenting symptoms, such as memory loss, but that extracellular Glu levels may also be a useful early biomarker and early therapeutic target of AD.

A $\beta P P / P S 1$ mice, an established model of $\mathrm{AD}$, are cognitively normal and lack AD neuropathology at 2-4 months of age, but begin showing cognitive decline and amyloid plaque accumulation at approximately $6-8$ months of age $[18,29-36]$. In the present studies, 
we examined cognition (Morris water maze; MWM) and Glu neurotransmission (in vivo electrochemistry) in the CA1, CA3, and dentate gyrus (DG) regions of the hippocampus in 2-4 month anesthetized A $\beta P P / P S 1$ mice.

\section{MATERIALS AND METHODS}

\section{Animals}

A $\beta P P / P S 1$ mice are double transgenic mice expressing a chimeric mouse/human amyloid- $\beta$ protein precursor (Mo/HuAPP695swe) and a mutant human presenilin 1 (PS1-dE9). Both mutations were directed to CNS neurons and have been associated with early-onset AD. Two to four month old group housed, male A $\beta$ PP/PS1 (B6.Cg-Tg(APPswe, PSEN1dE9)85Dbo/J; 034832) and C57BL/6J (000664) mice were obtained from Jackson Laboratory (Bar Harbor, ME) and used for all experiments. Protocols for animal use were approved by the Laboratory Animal Care and Use Committee at Southern Illinois University School of Medicine. Animals were housed according to approved guidelines, on a $12: 12 \mathrm{~h}$ light: dark cycle, and food and water were available ad libitum.

\section{Morris water maze}

MWM consisted of five consecutive learning days where mice were placed in a large tank of opaque water at various starting positions. The mice were trained to navigate to a platform at a fixed point based on visual cues, and remain there for $10 \mathrm{~s}$. Mice underwent three swimming trials on each of the five training days, with a minimum of $20 \mathrm{~min}$ between trials. Mice had two rest days prior to undergoing a single probe trial. During the probe, mice were placed in the tank of water for $60 \mathrm{~s}$, without the platform. Data parameters were recorded using video tracking software with the ANY-maze system (Stoelting Co., Wood Dale, IL, USA).

\section{Glutamate recordings}

Enzyme-based microelectrode arrays (MEA) with platinum recording sites were obtained from CenMeT (Lexington, KY). Twenty MEAs were used for this study with an average Glu sensitivity of 11.7 $\mathrm{pA} / \mu \mathrm{M}\left(\mathrm{R}^{2}=0.996\right)$, selectivity ratio over ascorbic acid of $386: 1$, and a signal-to-noise ratio of $0.5 \mu \mathrm{M}$. A single barrel glass micropipette was attached to the MEA assembly to locally apply isotonic $\mathrm{KCl}(\mathrm{pH}$ 7.4) [37, 38]. Mice were anesthetized with isoflurane and the MEA assemblies were lowered into the CA1 (AP: -2.0, ML: $\pm 1.0, \mathrm{DV}:-1.7 \mathrm{~mm}$ ), DG (AP: $-2.0, \mathrm{ML}: \pm 1.0, \mathrm{DV}:-2.2 \mathrm{~mm}$, or CA3 (AP: -2.0 , ML: $\pm 2.0, \mathrm{DV}:-2.2 \mathrm{~mm}$ ) based on coordinates from Paxinos and Franklin [39]. Solutions were pressure ejected from the micropipette using a Picospritzer (Parker Hannafin, Morton, IL) and volumes were monitored using a stereomicroscope fitted with a reticule. A constant volume of $70 \mathrm{mM} \mathrm{KCl}(\sim 100-200 \mathrm{~nL})$ was used to elicit Glu release to allow for direct comparisons between the groups. Amperometric data, time, and pressure ejection marks were recorded and analyzed using a FASTmkIII system and FAST Analysis Version 5.2 software (Quanteon, LLC, Nicholasville, KY, USA).

\section{Data analysis}

Data from MWM training days was analyzed using a two-way ANOVA followed by a Fisher's LSD posthoc test and probe data was analyzed using an unpaired Student's $t$-test. Glu data was analyzed using a one-way ANOVA followed by a Fisher's LSD post-hoc test. Correlations between MWM and Glu data were established using Pearson's correlation. Data was reported as mean \pm SEM and significance was defined as $p<0.05$. Seven to ten mice were used per group.

\section{RESULTS}

\section{Morris water maze}

All mice underwent cognitive testing using the MWM prior to in vivo Glu measures. Parameters analyzed for the initial five training days included duration, distance, average speed, path efficiency, and time spent in target quadrant. Parameters analyzed for the single probe trial included those previously mentioned and the number of platform entries, time spent in annulus 40, latency, distance, and path efficiency to first platform entry. During the single day probe session, AßPP/PS1 mice $(0.261 \pm 0.005 \mathrm{~m} / \mathrm{s})$ swam significantly $(p<0.05)$ faster compared to C57BL/6J mice $(0.240 \pm 0.009 \mathrm{~m} / \mathrm{s})$. To account for differences in swimming speed, we normalized probe data to total distance swam (in meters) for each mouse. We did not observe differences between genotypes during training or probe in any of the parameters measured (data not shown) as reported elsewhere [35]. 

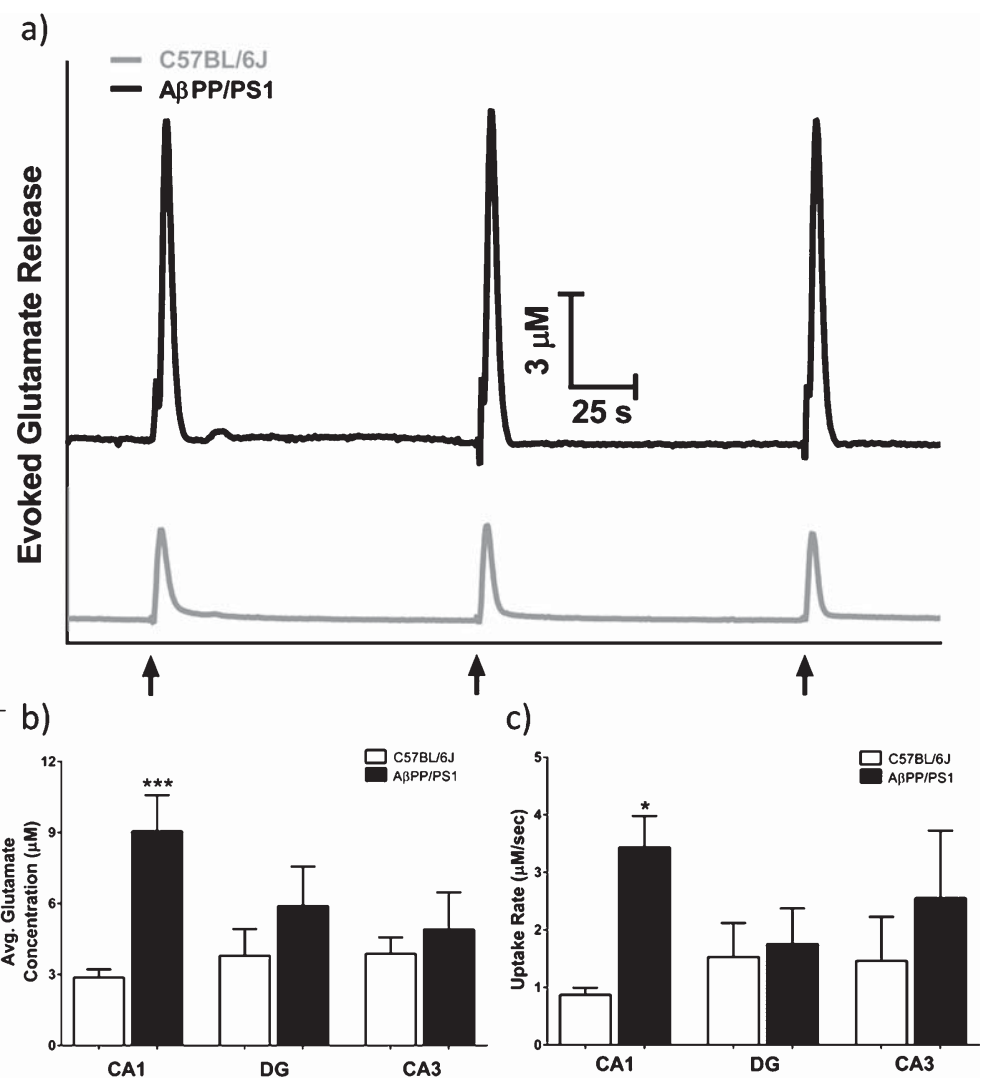

Fig. 1. KCl-evoked Glu release and uptake in the hippocampus. a) Representative traces taken from the CA1 of A $3 P P / P S 1$ mice (black line) and C57BL/6J mice (gray line). Arrows indicate local application of $70 \mathrm{mM} \mathrm{KCl} \mathrm{(150-200} \mathrm{nl).} \mathrm{b,} \mathrm{c)} \mathrm{KCl-evoked} \mathrm{Glu} \mathrm{release} \mathrm{and} \mathrm{uptake,} \mathrm{respectively,}$ was significantly elevated in the CA1 region of the hippocampus of A $\beta P P / P S 1$ mice compared to C57BL/6J mice, but not in the DG or CA3. Seven to ten mice were used per group. ${ }^{*} p<0.05 ;{ }^{* * *} p<0.001$ based on a one-way ANOVA with a Fisher's LSD post-hoc.

\section{Glutamate measures}

Basal Glu levels were similar in all hippocampal subregions $(\sim 1.0 \mu \mathrm{M}$; data not shown). We observed significantly more $\mathrm{KCl}$-evoked Glu release in the CA1 of A $\beta P P / P S 1$ mice compared to age-matched controls $(9.1 \pm 1.5 \mu \mathrm{M}$ versus $2.9 \pm 0.3 \mu \mathrm{M}$, respectively; $p<0.001$ ), however, no differences were observed in the DG or CA3 (Fig. 1a,b). Glu clearance (time from peak amplitude back to basal levels) from the extracellular space was similar in the CA1 of the A $\beta P P / P S 1$ mice compared to controls (representative traces, Fig. 1a). However, there was an approximate three-fold increase in Glu uptake rate in the CA1 of AßPP/PS1 mice compared to controls $(3.4 \pm 0.5 \mu \mathrm{M} / \mathrm{s}$ versus. $0.9 \pm 0.1 \mu \mathrm{M} / \mathrm{s}$, respectively; $p<0.05)$, which accounts for similar clearance times (Fig. 1c). Additionally, we observed a strong negative correlation $(r=-0.621)$ between $\mathrm{KCl}$-evoked Glu release in the CA1 and the number of platform entries per meter swam during the probe trial in the A $\beta P P / P S 1$ mice
(Fig. 2, solid line; $p=0.10$ ), while no correlation $(r=-0.036)$ was observed in the C57BL/6J control mice (Fig. 2; dashed line; $p=0.93$ ).

\section{DISCUSSION}

Similar to previous reports, we did not observe learning and/or memory differences in 2-4 month old A $\beta P P / P S 1$ mice compared to age-matched controls, supporting that $\mathrm{A} \beta \mathrm{PP} / \mathrm{PS} 1$ mice in this age range remain cognitively intact [32]. While basal Glu levels were similar in all hippocampal subregions, we did observe increased potassium-evoked Glu release in 2-4 month A $\beta P P / P S 1$ mice. Consistent with our basal Glu findings, researchers using magnetic resonance spectroscopy (MRS) in 2-4 month AßPP/PS1 mice have shown no differences in hippocampal Glu metabolite levels compared to age-matched controls [40, 41]. However, stimulus evoked release was not examined in these MRS studies nor is MRS specific 


\section{CA1}

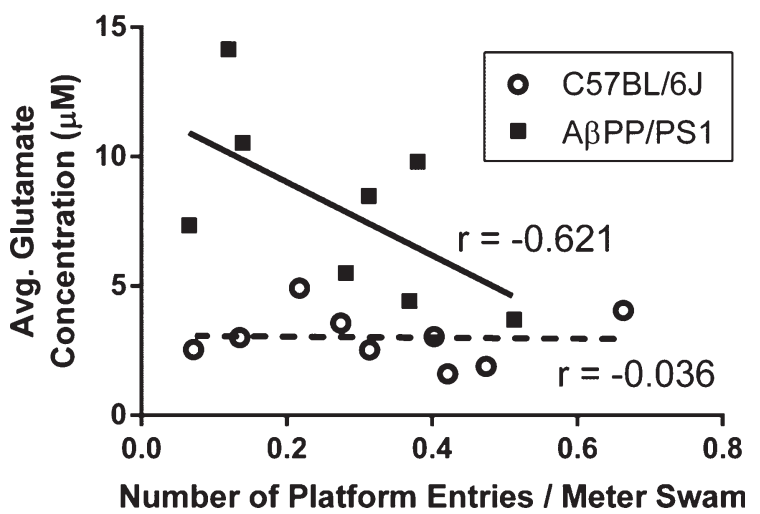

Fig. 2. KCl-evoked Glu release in the CA1 versus number of platform entries per meter swam. Correlation of $\mathrm{KCl}$-evoked Glu release in the CA1 (Fig. 1b) with the number of platform entries per meter swam during the probe session of MWM. Pearson's correlation when evaluating A $\beta P P / P S 1$ mice was $r=-0.621 \quad(p=0.10$; solid line). Pearson's correlation when evaluating C57BL/6J mice was $r=-0.036(p=0.93$; dashed line $)$.

enough to elucidate the subregional hippocampal differences observed in the present study. Only changes in CA1 evoked-Glu release were observed, which corresponds to the neuropathological progression of AD. Magnetic resonance imaging studies have shown that hippocampal atrophy begins in the CA1 subfield of mild cognitively impaired patients and then affects other subregions as the diseases progresses to AD [42], a finding consistent with the Braak stages of $\mathrm{AD}$ [43].

Interestingly, there was no difference in the time it took to clear Glu from the extracellular space in the CA1 despite evoked Glu release being approximately three times greater in the A $\beta P P / P S 1$. This was likely due to an approximate three-fold increase in uptake rate in the $\mathrm{CA} 1$ of $\mathrm{A} \beta \mathrm{PP} / \mathrm{PS} 1$ mice, which may indicate that the numbers of glial Glu transporters are increased as a compensatory mechanism to prevent excitotoxicity.

The increased $\mathrm{KCl}$-evoked Glu release in the CA1 negatively correlated with performance on the memory portion of the MWM task. This correlation supports a specific threshold of Glu release in A $\beta P P / P S 1$ mice that negatively impacts memory formation or information recall, possibly due to overactivation of $\mathrm{N}$-methyl-D-aspartate (NMDA) receptors that causes impairments in new learning and memory before the onset of excitotoxicity [44].

Taken together, these data support that altered Glu neurotransmission precedes neuropathology and cognitive decline in A $\beta P P / P S 1$ mice and may be a potential early biomarker for AD. Future studies will evaluate Glu levels and kinetics during and after cognitive decline in A $\beta P P / P S 1$ mice to understand how Glu neurotransmission changes during $\mathrm{AD}$ progression as well as exploring potential therapeutic treatments.

\section{ACKNOWLEDGMENTS}

This research was supported by funds obtained from the Center for Alzheimer's Disease and Related Disorders at Southern Illinois University School of Medicine.

Authors' disclosures available online (http://www.jalz.com/disclosures/view.php?id=2582).

\section{REFERENCES}

[1] Fargo K, Bleiler L (2014) 2014 Alzheimer's disease facts and figures. Alzheimers Dement 10, e47-e92.

[2] Bero AW, Yan P, Roh JH, Cirrito JR, Stewart FR, Raichle ME, Lee J-M, Holtzman DM (2011) Neuronal activity regulates the regional vulnerability to amyloid- $\beta$ deposition. Nat Neurosci 14, 750-756.

[3] Olney JW, Wozniak DF, Farber NB (1997) Excitotoxic neurodegeneration in Alzheimer disease. New hypothesis and new therapeutic strategies. Arch Neurol 54, 1234-1240.

[4] Cleary JP, Walsh DM, Hofmeister JJ, Shankar GM, Kuskowski MA, Selkoe DJ, Ashe KH (2005) Natural oligomers of the amyloid-beta protein specifically disrupt cognitive function. Nat Neurosci 8, 79-84.

[5] Li S, Jin M, Koeglsperger T, Shepardson NE, Shankar GM, Selkoe DJ (2011) Soluble A $\beta$ oligomers inhibit long-term potentiation through a mechanism involving excessive activation of extrasynaptic NR2B-containing NMDA receptors. J Neurosci 31, 6627-6638.

[6] Rush T, Buisson A (2014) Reciprocal disruption of neuronal signaling and $A \beta$ production mediated by extrasynaptic NMDA receptors: A downward spiral. Cell Tissue Res $\mathbf{3 5 6}$ 279-286.

[7] Walsh DM, Klyubin I, Fadeeva JV, Cullen WK, Anwyl R, Wolfe MS, Rowan MJ, Selkoe DJ (2002) Naturally secreted oligomers of amyloid beta protein potently inhibit hippocampal long-term potentiation in vivo. Nature 416, 535-539.

[8] Verkhratsky A, Olabarria M, Noristani HN, Yeh C-Y, Rodriguez JJ (2010) Astrocytes in Alzheimer's disease. Neurotherapeutics 7, 399-412.

[9] Talantova M, Sanz-Blasco S, Zhang X, Xia P, Akhtar MW, Okamoto S, Dziewczapolski G, Nakamura T, Cao G, Pratt AE, Kang Y-J, Tu S, Molokanova E, McKercher SR, Hires SA, Sason H, Stouffer DG, Buczynski MW, Solomon JP, Michael S, Powers ET, Kelly JW, Roberts A, Tong G, FangNewmeyer T, Parker J, Holland EA, Zhang D, Nakanishi N, Chen H-SV, Wolosker H, Wang Y, Parsons LH, Ambasudhan R, Masliah E, Heinemann SF, Piña-Crespo JC, Lipton SA (2013) A $\beta$ induces astrocytic glutamate release, extrasynaptic NMDA receptor activation, and synaptic loss. Proc Natl Acad Sci U S A 110, E2518-E2527.

[10] Paula-Lima AC, Brito-Moreira J, Ferreira ST (2013) Deregulation of excitatory neurotransmission underlying synapse failure in Alzheimer's disease. J Neurochem 126, 191202. 
[11] Kirvell SL, Esiri M, Francis PT (2006) Down-regulation of vesicular glutamate transporters precedes cell loss and pathology in Alzheimer's disease. J Neurochem 98, 939-950.

[12] Bell KFS, Bennett DA, Cuello AC (2007) Paradoxical upregulation of glutamatergic presynaptic boutons during mild cognitive impairment. J Neurosci 27, 10810-10817.

[13] Gasparini L, Dityatev A (2008) Beta-amyloid and glutamate receptors. Exp Neurol 212, 1-4.

[14] Hoey SE, Buonocore F, Cox CJ, Hammond VJ, Perkinton MS, Williams RJ (2013) AMPA receptor activation promotes non-amyloidogenic amyloid precursor protein processing and suppresses neuronal amyloid- $\beta$ production. PLoS One 8 , e78155.

[15] Hsieh H, Boehm J, Sato C, Iwatsubo T, Tomita T, Sisodia S, Malinow R (2006) AMPAR removal underlies Abeta-induced synaptic depression and dendritic spine loss. Neuron 52, 831843.

[16] Kabogo D, Rauw G, Amritraj A, Baker G, Kar S (2010) $\beta$-amyloid-related peptides potentiate $\mathrm{K}+$-evoked glutamate release from adult rat hippocampal slices. Neurobiol Aging 31, 1164-1172.

[17] Mattson MP, Pedersen WA, Duan W, Culmsee C, Camandola S (1999) Cellular and molecular mechanisms underlying perturbed energy metabolism and neuronal degeneration in Alzheimer's and Parkinson's diseases. Ann N Y Acad Sci 893, 154-175.

[18] Minkeviciene R, Ihalainen J, Malm T, Matilainen O, KeksaGoldsteine V, Goldsteins G, Iivonen H, Leguit N, Glennon J, Koistinaho J, Banerjee P, Tanila H (2008) Age-related decrease in stimulated glutamate release and vesicular glutamate transporters in APP/PS1 transgenic and wild-type mice. J Neurochem 105, 584-594.

[19] Mitew S, Kirkcaldie MTK, Dickson TC, Vickers JC (2013) Altered synapses and gliotransmission in Alzheimer's disease and AD model mice. Neurobiol Aging 34, 2341-2351.

[20] Mookherjee P, Green PS, Watson GS, Marques MA, Tanaka K, Meeker KD, Meabon JS, Li N, Zhu P, Olson VG, Cook DG (2011) GLT-1 loss accelerates cognitive deficit onset in an Alzheimer's disease animal model. J Alzheimers Dis $\mathbf{2 6}$, 447-455.

[21] Pirttimaki TM, Codadu NK, Awni A, Pratik P, Nagel DA, Hill EJ, Dineley KT, Parri HR (2013) $\alpha 7$ Nicotinic receptormediated astrocytic gliotransmitter release: $\mathrm{A} \beta$ effects in a preclinical Alzheimer's mouse model. PLoS One 8, e81828.

[22] Schallier A, Smolders I, Van Dam D, Loyens E, De Deyn PP, Michotte A, Michotte Y, Massie A (2011) Region- and agespecific changes in glutamate transport in the A $\beta P P 23$ mouse model for Alzheimer's disease. J Alzheimers Dis 24, 287-300.

[23] Scimemi A, Meabon JS, Woltjer RL, Sullivan JM, Diamond JS, Cook DG (2013) Amyloid- $\beta 1-42$ slows clearance of synaptically released glutamate by mislocalizing astrocytic GLT-1. J Neurosci 33, 5312-5318

[24] Shankar GM, Bloodgood BL, Townsend M, Walsh DM, Selkoe DJ, Sabatini BL (2007) Natural oligomers of the Alzheimer amyloid-beta protein induce reversible synapse loss by modulating an NMDA-type glutamate receptordependent signaling pathway. J Neurosci 27, 2866-2875.

[25] Sokolow S, Luu SH, Nandy K, Miller CA, Vinters HV, Poon WW, Gylys KH (2012) Preferential accumulation of amyloidbeta in presynaptic glutamatergic terminals (VGluT1 and VGluT2) in Alzheimer's disease cortex. Neurobiol Dis $\mathbf{4 5}$ 381-387.

[26] Wenk GL (2006) Neuropathologic changes in Alzheimer's disease: Potential targets for treatment. J Clin Psychiatry 67(Suppl 3), 3-7; quiz 23.
[27] Zádori D, Veres G, Szalárdy L, Klivényi P, Toldi J, Vécsei L (2014) Glutamatergic dysfunctioning in Alzheimer's disease and related therapeutic targets. J Alzheimers Dis 42(Suppl 3), S177-S187.

[28] Parameshwaran K, Dhanasekaran M, Suppiramaniam V (2008) Amyloid beta peptides and glutamatergic synaptic dysregulation. Exp Neurol 210, 7-13.

[29] Bernardo A, Harrison FE, McCord M, Zhao J, Bruchey A, Davies SS, Jackson Roberts L, Mathews PM, Matsuoka Y, Ariga T, Yu RK, Thompson R, McDonald MP (2009) Elimination of GD3 synthase improves memory and reduces amyloid-beta plaque load in transgenic mice. Neurobiol Aging 30, 1777-1791.

[30] Cao D, Lu H, Lewis TL, Li L (2007) Intake of sucrosesweetened water induces insulin resistance and exacerbates memory deficits and amyloidosis in a transgenic mouse model of Alzheimer disease. J Biol Chem 282, 3627536282 .

[31] Ding Y, Qiao A, Wang Z, Goodwin JS, Lee E-S, Block ML, Allsbrook M, McDonald MP, Fan G-H (2008) Retinoic acid attenuates beta-amyloid deposition and rescues memory deficits in an Alzheimer's disease transgenic mouse model. $J$ Neurosci 28, 11622-11634.

[32] Gimbel DA, Nygaard HB, Coffey EE, Gunther EC, Laurén J, Gimbel ZA, Strittmatter SM (2010) Memory impairment in transgenic Alzheimer mice requires cellular prion protein. $J$ Neurosci 30, 6367-6374.

[33] Lalonde R, Kim HD, Maxwell JA, Fukuchi K (2005) Exploratory activity and spatial learning in 12-month-old APP(695)SWE/co+PS1/DeltaE9 mice with amyloid plaques. Neurosci Lett 390, 87-92.

[34] Reiserer RS, Harrison FE, Syverud DC, McDonald MP (2007) Impaired spatial learning in the APPSwe + PSEN1DeltaE9 bigenic mouse model of Alzheimer's disease. Genes Brain Behav 6, 54-65.

[35] Webster SJ, Bachstetter AD, Nelson PT, Schmitt FA, Van Eldik LJ (2014) Using mice to model Alzheimer's dementia: An overview of the clinical disease and the preclinical behavioral changes in 10 mouse models. Front Genet 5, 88 .

[36] Webster SJ, Bachstetter AD, Van Eldik LJ (2013) Comprehensive behavioral characterization of an APP/PS-1 double knock-in mouse model of Alzheimer's disease. Alzheimers Res Ther 5, 28.

[37] Hascup KN, Bao X, Hascup ER, Hui D, Xu W, Pomerleau F, Huettl P, Michaelis ML, Michaelis EK, Gerhardt GA (2011) Differential levels of glutamate dehydrogenase 1 (GLUD1) in $\mathrm{Balb} / \mathrm{c}$ and $\mathrm{C} 57 \mathrm{BL} / 6$ mice and the effects of overexpression of the Glud1 gene on glutamate release in striatum. ASN Neuro 3, pii: e00057.

[38] Burmeister JJ, Pomerleau F, Palmer M, Day BK, Huettl P, Gerhardt GA (2002) Improved ceramic-based multisite microelectrode for rapid measurements of L-glutamate in the CNS. J Neurosci Methods 119, 163-171.

[39] Paxinos G, Franklin KBJ (2004) The Mouse Brain in Stereotaxic Coordinates, Elsevier Science, San Diego.

[40] Chen S, Cai Q, Shen Y, Wang P, Teng G, Zhang W, Zang F (2012) Age-related changes in brain metabolites and cognitive function in APP/PS1 transgenic mice. Behav Brain Res 235, $1-6$.

[41] Oberg J, Spenger C, Wang F-H, Andersson A, Westman E, Skoglund P, Sunnemark D, Norinder U, Klason T, Wahlund L-O, Lindberg M (2008) Age related changes in brain metabolites observed by $1 \mathrm{H}$ MRS in APP/PS1 mice. Neurobiol Aging 29, 1423-1433. 
[42] Frankó E, Joly O (2013) Evaluating Alzheimer's disease progression using rate of regional hippocampal atrophy. PLoS One 8, e71354.

[43] Braak H, Braak E. Staging of Alzheimer's disease-related neurofibrillary changes. Neurobiol Aging 16, 271-8; discussion 278-84.
[44] Parsons CG, Stöffler A, Danysz W (2007) Memantine: A NMDA receptor antagonist that improves memory by restoration of homeostasis in the glutamatergic system-too little activation is bad, too much is even worse. Neuropharmacology $\mathbf{5 3}, 699-723$. 